Golden Gate University School of Law GGU Law Digital Commons

\title{
A Shallow Fix: The Uniform Environmental Covenants Act Leaves Hard Brownfield Questions Unanswered
}

\author{
Paul Stanton Kibel \\ Golden Gate University School of Law, pkibel@ggu.edu
}

Follow this and additional works at: http:// digitalcommons.law.ggu.edu/pubs

Part of the Environmental Law Commons

\section{Recommended Citation}

57 Planning and Environmental Law 3 (Feb. 2005)

This Article is brought to you for free and open access by the Faculty Scholarship at GGU Law Digital Commons. It has been accepted for inclusion in Publications by an authorized administrator of GGU Law Digital Commons. For more information, please contact jischer@ggu.edu. 


\section{A Shallow Fix: The Uniform Environmental Covenants Act Leaves Hard Brownfield Questions Unanswered}

Paul Stanton Kibel. Planning \& Environmental Law. Chicago: Feb 2005. Vol. 57, Iss. 2; pg. 3, 6 pgs

\section{Abstract (Summary)}

The shortcomings of UECA are on the front end, at the point when state and local environmental agencies decide to approve environmental covenants at a particular site.

Copyright American Planning Association Feb 2005

Restoring abandoned urban properties to productive use is essential to curtail metropolitan sprawl. Uncertain liability regarding subsurface contamination at such sites, however, is often an obstacle to such restoration efforts. Current owners frequently avoid conducting soil and groundwater testing for fear that what they find may trigger an expensive cleanup. Yet without such investigation, it is often difficult to attract investment or financing because developers and banks fear potential cleanup costs as well.

This is the liability dynamic that impedes the remediation and reuse of many properties with subsurface environmental liability concerns. Such properties are commonly known as "brownfields" and are often found in urban communities with a high percentage of low-income, minority residents.

One response to the brownfield liability dynamic has been the joint promotion of riskbased correction action (RBCA) standards for environmental cleanups along with legallyenforceable restrictions on future land uses. These two approaches work together in the following manner. An agency with environmental oversight at a property agrees to permit a less expensive remediation tailored to the limited uses of the property proposed by the current owner. In exchange, the owner agrees to record a deed restriction legally committing itself and its successors to these proposed limited uses. Examples of this tandem adoption of RBGA standards and land use restrictions would be a cleanup that assumes, and a deed restriction that requires, that a property will not be used for residential purposes or that there will not be excavation of soil beyond a certain depth. By capping the extent and expense of cleanups, these approaches seek to stimulate investment in brownfields.

The majority of brownfields in the United States sites are regulated by state and local environmental agencies rather than the federal Environmental Protection Agency (EPA). These state and local environmental agencies have developed different terminology to describe the reliance on legally enforceable property use restrictions to facilitate less expensive RBCA cleanups. Some agencies refer to them as institutional controls, while other agencies refer to them as land use covenants, land use controls, or environmental deed restrictions. The procedures developed by different agencies to implement these 
contamination-based property restrictions are as varied as the terminology used to refer to them. Many of these agency procedures are difficult to reconcile with real estate law, which traditionally does not provide a role for administrative agencies and the general public in recording and enforcing deed restrictions.

In an effort to standardize the different approaches taken by various state and local environmental agencies around the country, and to better synthesize them with real estate law, the National Conference of Commissioners on Uniform State Laws (NCCLISL) adopted the Uniform Environmental Covenants Act (UECA) in August 2003.1 NCCUSL has recommended UECA for adoption by individual states. Among other things, UECA proposes the term "environmental covenants" to refer generally to enforceable property use restrictions allowing more limited remediation of hazardous substances, and sets forth provisions for how to record and enforce such environmental covenants.2

Although UECA's general goal of harmonization may be laudable, UECA's provisions leave many critical brownfield questions unanswered. Most significantly, UECA does not set forth criteria or procedures to determine when it is inappropriate for an environmental agency to reduce cleanup costs by approving less comprehensive cleanups and by prohibiting otherwise lawful land uses. NCCUSL intentionally left this thorny question to state and local agencies, and instead focused UECA on integrating the mechanics of the environmental covenant recordation and enforcement process with traditional real estate law.

As explained below, although NCCUSL's aversion to dealing with this thorny issue may be understandable in light of the origins of the UECA drafting process, this aversion nonetheless renders the current UECA an incomplete piece of legislation. In its present form, UECA facilitates and validates an approach to environmental cleanups and land use without requiring sufficient safeguards to prevent this approach from being misused at the expense of local communities and public health. In theory, state or local agencies could provide these missing pieces, but experience to date has shown they often don't.

\section{ENVIRONMENTAL COVENANTS AS LAND USE POLICY}

One of the primary concerns about the potential misuse of environmental covenants relates to their role as "backdoor zoning."

State and local law generally set forth a detailed legislative process for determining the types of land uses and activities permitted in particular neighborhoods. 3 General land use plans (general plans) and zoning codes usually must be approved by an elected city council or county board of supervisors, and revisions to general plans and zoning codes usually also require the approval of such legislative bodies and then only after a public comment period and hearing. 4 The adoption of environmental covenants by environmental regulatory agencies, however, often bypasses the transparency and political accountability in the land use policy arena provided by traditional general plan and zoning law. 
The current situation along the City of Oakland's estuary waterfront provides an example of how environmental covenants can result in backdoor zoning. There are many underutilized parcels along the Oakland waterfront that have historically been used, and are presently being used, for industrial or manufacturing purposes. These uses have often resulted in the release of hazardous substances into the subsurface, which in turn has attracted the attention of state and county environmental agencies. To avoid potentially expensive cleanups, owners of such waterfront sites have increasingly approached these agencies about recording environmental covenants to prohibit future use of the land for residential purposes. This approach all seems well and good until one considers the larger economic and community context.

In recent years, the City of Oakland adopted zoning code changes and a comprehensive Estuary Policy Plan that provides for the transition of many sites previously used for industry and manufacturing to residential and parkland use. 5 These actions were prompted by a shortage of housing and parkland in the area and indications that many industrial and manufacturing operations would no longer be economically viable at these locations in the future. In addition, a significant percentage of the population in Oakland's waterfront neighborhoods are low-income African-American and Latino residents, and there was concern about the public health impacts of industrial and manufacturing operations on the surrounding community.

The changes in land use along the waterfront proposed by the City of Oakland, however, are at odds with many of the environmental covenants now being approved by state and county environmental agencies. These environmental covenants are designed to lock in current industrial and manufacturing uses indefinitely, and to enable current owners to avoid responsibility for cleaning up subsurface conditions to levels that would permit conversion of a site to residential or parkland use. Thus, although the city zoning code and land use law permits and encourages the transition of the waterfront from industrial and manufacturing uses to residential and parkland uses, non-city environmental agencies are approving environmental covenants that may make this transition impossible for some parcels.

This is not to suggest that the use of environmental covenants is inappropriate for all properties. There are indeed situations where circumstances suggest that it is the right course of action, such as when the property restrictions proposed in the environmental covenant are consistent with planning agency's and the surrounding community's longterm land use plans for a parcel. Rather, what the Oakland waterfront situation reveals is that determinations of whether an environmental covenant is appropriate for a particular site need to take proper account of broader local land use policies and community considerations. This recognition is something that seems to have been lost in NCCUSL's drafting of UECA.

For instance, Amy L. Edwards, an environmental attorney who served as an official observer to NCCUSL's UECA drafting committee, remarked in an article on UECA that the only way for brownfields reuse to succeed on a national level is if responsible parties are allowed to use risk-based corrective action." Edwards's comment suggests the view 
that risk-based remediation standards, which are often used in conjunction with environmental covenants, are an appropriate approach for any brownfield site. A blanket endorsement of this approach does not reflect the potential for risk-based cleanups and environmental covenants to conflict with land use law and competing community objectives. As noted below, it appears that such thinking-which posits the use of environmental covenants as an inherently good thing, as opposed to an occasionally good thing fraught with opportunities for misuse-was an assumption that permeated the UECA drafting process.

\section{UECA DRAFTING PROCESS}

The origins of NCCUSL's UECA drafting process go a long way towards explaining why certain hard brownfields questions were not addressed.

Of paramount importance, the initial idea for UECA did not come from environmental groups or even from federal, state, or local environmental agencies. Rather, the UECA proposal came from the United States Department of Defense (a federal umbrella agency for the Army, Air Force, and Navy) to help streamline environmental cleanups at military sites around country. In September 2001, the Defense Department entered into a contract with NCCUSL for "Research and Drafting of a Uniform Environmental Covenants and Land Use Controls Act."7 The Defense Department footed the entire bill for the UECA drafting process, which was budgeted for $\$ 150,000.8$ From the very beginning, therefore, the impetus and funding behind UECA came from a federal stakeholder agency whose primary concern was expediting cleanups on property it owned, and with no particular expertise or responsibility for public health or land use zoning.

In implementing its UECA contract with the Defense Department, NCCUSL assembled a drafting committee that included many recognized experts in the fields of environmental and real estate law, including Professors William Breetz and Kurt Strasser of the University of Connecticut Law School." Representatives from the Defense Department, EPA, and state environmental agencies also served on the drafting committee. In reviewing the members of the UECA drafting committee, what is particularly striking is the absence of representatives from environmental advocacy organizations such as the Sierra Club, Natural Resources Defense Council, or Environmental Defense. There were also no representatives from the federal National Environmental Justice Advisory Council (NEJAC), which focuses on the impact of toxics policy on low-income and minority populations. 10 John Pendergrass, a well-respected senior attorney with the Environmental Law Institute (ELI) in Washington, D.C., was part of the UECA drafting team assembled by NCCUSL.11 ELI's role, however, is generally to find policy consensus among different stakeholders affected by environmental regulation rather than to specifically advocate for strengthened environmental protection.

The composition of the UECA drafting committee is very telling. It suggests that NCCUSL and the Defense Department may not have been particularly interested in having UECA drafting committee members who were likely to express strong reservations about whether the use of environmental covenants should be encouraged. It 
also suggests that the main national environmental advocacy groups may not have considered the adoption of UECA as a wise policy course, and therefore were not inclined to lend their support to NCCUSL's effort. Regardless of why strong environmental protection interests were not present, their absence appears to have contributed to the underlying assumption by the UECA drafting committee that facilitating the use of environmental covenants is a good idea. This assumption is reflected in many of NCCUSL's drafting documents.

For instance, in the prefatory note that accompanied the release of the final version of UECA in August 2003, NCCUSL states:

An environmental covenant typically is used when the real property is to be cleaned up to a level determined by the potential environmental risks posed by a particular use, rather than to unrestricted use standards. Such risk-based remediation is both environmentally and economically preferable in many instances .... Large numbers of contaminated sites are unlikely to be successfully recycled until regulators, potentially responsible parties, affected communities, prospective purchasers and their lenders become confident that environmental covenants will be properly drafted, implemented, monitored and enforced for so long as needed.12

These comments hint that there may indeed be situations when the use of risk-based remediation and environmental covenants is not "environmentally and economically preferable," but do not provide any further guidance on, or analysis of, this point. Significantly, the prefatory note for UECA does not explain the basis for its counterintuitive suggestion that a partial risk-based cleanup tied to restricted property uses is often "environmentally preferable" to a more comprehensive cleanup where use restrictions are not required.

Similarly, on March 24, 2003, NCCUSL issued a press release with the heading "The Uniform Environmental Covenants Act Nears Completion."13 This press release declared:

An environmental covenant is typically used when it is necessary to clean up contaminated property to a level determined by the environmental risks posed, rather than to unrestricted use standards .... [UECA] can help return previously contaminated property, often located in urban areas, to the stream of commerce, reducing the dangers such contamination poses to our citizens, and improving the quality of the environment in which we live. 14

This press release gives the impression that there is consensus among environmentalists, public health advocates, and urban communities that environmental covenants should be used more widely. In fact, there is no such consensus. 15

As University of Arizona Law Professor Kirsten Engel notes: 
Due to the low land value prevailing in their communities together with their relative political powerlessness, poor and minority communities have been targeted historically as sites for heavy industrial development and, as a result, are subject to a disproportionate share of the environmental hazards that frequently accompany such development. Rather than reverse this legacy, brownfield cleanups could actually perpetuate it. If for example, the cleanup of a brownfield site is sufficient only for future industrial uses, the community will never escape this industrial legacy but will continue to be located near potentially environmentally hazardous industrial development. 16

The UECA drafting documents do not reflect an awareness or understanding of such concerns.

As a final example, prior to entering into the formal September 2001 contract with the Defense Department, NCCUSL assembled a UECA study committee. Many of the members of the UECA study committee went on to later serve on the UECA drafting committee. On July 23, 2001, the UECA study committee released a 12-page recommendations report noting that the use of environmental covenants is "complicated from the perspective of local communities" and that "[c]ommunity developers and local land use planners are not usually a part of the negotiating process regarding the disposition of Federal land and the negotiation of various land use controls." 17 The report further commented that "some opposition might be expected from environmental groups who are opposed in principle to risk-based cleanups and hence oppose anything that makes risk-based cleanups more workable." 18

These UECA study committee report comments reflect some recognition by NCCUSL that local communities and land use planners are often excluded from decisions about when it is appropriate to permit the use of an environmental covenant. There is no indication in these comments, however, that this was a consideration that would factor into NCCUSL's drafting of UECA. The comments also suggest a misunderstanding of why there is often opposition to the use of environmental covenants at particular sites. This opposition does not stem from an ideological rejection of risk-based analysis, but rather stems from practical concerns and actual experience that the use of risk-based corrective action in conjunction with environmental covenants often conflicts with other public health considerations and land use policies. These practical concerns include whether it makes sense to restrict a property to industrial use if it is located in an area whose economy is transitioning away from industrial uses, or whether it is appropriate for a particular residential site to be completely paved over to prevent residents from coming into contact with contaminated subsurface soils.

By characterizing such concerns as primarily ideological in nature, UECA's drafters were able to more easily discount them as wrongheaded and therefore not meriting closer scrutiny. This discounting enabled the drafters to focus their attention more on the concerns that had prompted the Defense Department to approach NCCUSL about a UECA, namely the better integration of traditional real estate law considerations in the context of the recording and enforcement of environmental covenants. 
When judged by the limited parameters and goals adopted as part of the UECA drafting process, NCCUSL was by and large successful. UECA includes many provisions that do in fact help reconcile the use of environmental covenants with traditional real estate law. For instance, UECA clarifies that the land use restrictions set forth in environmental covenants are servitudes that run with the land and must have designated grantors and grantees. 19 As another example, UECA exempts environmental covenants from the requirements of the Uniform Marketable Title Act, which provides that most restrictive property covenants expire after a set period of time unless rerecorded.20 UECA also provides for enforcement of environmental covenants by the grantor, the grantee, the environmental agency, local municipal governments, and other parties with a tangible interest in the real property-an expansion of the more limited enforcement provisions for most other deed restrictions. 21

By themselves, these UECA provisions are not objectionable in their clarification of the legal status of environmental covenants. The problem, however, is that in clarifying the legal status of environmental covenants, UECA is also helping to facilitate their more widespread use. Given that there remains considerable apprehension about the inappropriate use of environmental covenants, UECA's facilitation of their widespread use seems to be putting the cart before the horse. Perhaps this is why UECA has so far received such a lackluster response from environmentalists.

\section{FRONT-END QUESTIONS}

The shortcomings of UECA are on the front end, at the point when state and local environmental agencies decide to approve environmental covenants at a particular site. Section 6 of UECA is entitled "Relationship to Other Land Use Law" and provides that "An environmental covenant may prohibit or restrict uses of real property which are authorized by zoning or by law other than this Act."22 NCCUSL's comment to Section 6 of UECA explains that "the Act contemplates that an environmental covenant might, for example, prohibit residential use on a parcel subject to a covenant .... [S] uch a prohibition or restriction in an environmental covenant will be valid even if other real property law, including local zoning, would authorize the use for residential purposes."23 It is here, in section 6, where UECA's omissions and inadequacies are most apparent.

Section 6 and its accompanying comment confirm that there will be cases where environmental covenants will expressly prohibit uses that zoning laws expressly permit, and that in such cases the restrictions in the environmental covenants will legally trump zoning law. Yet, and somewhat remarkably, UECA does not contain any further provisions or commentary that consider the implications of this position for the local legislative bodies that adopt zoning laws or the citizens who elect these legislative bodies. In drafting UECA, NCCUSL appears to have made no attempt to anticipate or accommodate the concerns of those who might disagree with the initial decision to use an environmental covenant at a particular site to reduce cleanup costs. More specifically, there are several provisions that NCCUSL could have included in UECA but did not in this regard, none of which would have intruded significantly on existing state or local law. 
For example, although UECA does not prohibit environmental agencies from working with local land use agencies before agreeing to environmental covenants at a particular site, it does not require environmental agencies to obtain the prior consent of such local land use agencies when restrictions on otherwise permitted uses are proposed. Such a prior consent provision would help ensure that local land use agencies are consulted beforehand and persuaded that a land use restriction proposed in an environmental covenant is not in conflict with broader zoning and general plan provisions.

As another example, UECA is silent on the question of providing appropriate opportunities for public comment on a proposed environmental covenant. Instead of this silence, UECA could have established that prior to entering into an agreement with an owner or developer of private property for the recordation of an environmental covenant, environmental agencies must provide a public comment period and hold a public hearing.

As a final example, UECA could have required that a state or local environmental agency prepare a land use restriction assessment before entering into an agreement with an owner or developer of private property for the recordation of an environmental covenant. This assessment could evaluate whether the use restrictions proposed in the environmental covenant limit land uses permitted or anticipated in zoning codes, general plans, or other community economic development plans. To the extent such conflicts exist, the assessment could explain why use of the proposed environmental covenant is nonetheless warranted in the particular instance.

Instead of including any of these front end requirements or some combination of them, UECA instead left it entirely to states and local governments to adopt (or not adopt) procedures to determine whether proposed environmental covenants conflict with local land use laws and to provide for public participation by the adjacent community. 24

To provide a mechanism to remove environmental covenants that are later found to be inappropriate, UECA does establish a back-end process wherein environmental covenants can be lifted either with a grantor's permission or without a grantor's permission if a court finds that removing the use restrictions will not have an adverse effect on human health and the environment.25 On a practical level, however, there are many limitations to this back-end approach.

First, once above-ground structures (such as factories or warehouses) have been built on a parcel in reliance on an environmental covenant, the very presence of these aboveground structures often renders additional subsurface remediation cost-prohibitive. Second, even if removal of an environmental covenant is ultimately approved by a court, UECA would likely shield the initial grantor from responsibility for additional cleanup costs. Third, the potential costs and uncertainty of litigation seeking the removal of an environmental covenant over a grantor's opposition provides grantors with considerable leverage to extract payments from those wishing to obtain the grantor's permission for such removal. As such, UECA's inclusion of back-end procedures to extinguish environmental covenants does not make up for its shortcomings on the front end. 


\section{OF DIRT AND SLUDGE}

The drafters and supporters of UEGA have described the act as the successful reconciliation of the concerns of "dirt" lawyers (real estate law attorneys) and "sludge" lawyers (environmental attorneys).26 One of the problems with this characterization, however, is that it fails to recognize that within the environmental bar, a distinction is often drawn between the "brown bar" (those attorneys who primarily represent clients seeking to reduce their financial liability for cleanup costs) and the "green bar" (those environmental attorneys who represent agencies or clients primarily seeking to strengthen protection of public health and the environment). The sludge lawyers referred to by UECA's drafters and supporters are generally associated with the brown bar and are therefore often considered suspect by members of the green bar and the environmental interests and organizations the green bar represents.

Without the support of the green bar and environmentalists, as well as urban neighborhoods where many brownfields are located, the prospects for UECA's adoption by states around the country looks less than promising. Assertions by NCCUSL, the Defense Department, and sludge lawyers that UECA is good for the environment, good for public health, and good for local communities are likely to be received with an appropriate dose of skepticism. As Professor Engel has indicated, this skepticism will remain unless there are effective mechanisms to ensure that the "probability of environmental harm is minimal and the potential economic benefits are large" to the communities where risk-based cleanups and environmental covenants are proposed.27 These are mechanisms that UECA presently lacks.

Instead of trying to persuade states to pass the current version of UECA over the objections of environmentalists, environmental justice advocates, and members of the green bar with legitimate concerns about the misuse of environmental covenants, a better course of action would be for NCCUSL to reopen the UECA drafting process and to make certain these other stakeholders participate this time around. With these formerly absent interests involved, it may be possible for NCCUSL to craft a revised UECA that meaningfully addresses the front-end complexities associated with environmental covenants. What the current version of UECA makes clear, however, is that the hard brownfield questions will not be answered if the hard brownfield questions are not asked.

\section{[Footnote]}

1. UNIFORM ENVIRONMENTAL COVENANTS ACT (2003) [hereinafter UECA], available at www. environmental-covenants.org.

2. UECA $\S 2(4)$.

3. See generally DANIEL CURTIN \& CECILY TALBERT, CURTIN'S CALIFORNIA LAND USE AND PLANNING LAW (24th ed. 2004).

4. id.

5. CITY OF OAKLAND AND PORT OF OAKLAND, ESTUARY POLICY PLAN 2-3 (1999).

6. Amy L. Edwards, A Brave New World: The Converging Worlds of Environmental and 
Real Estate Law at Environmentally Impaired Sites, Holland \& Knight News-

Environment, Third Quarter 2002), at 8-10.

7. Service Cooperative Agreement Schedule between United States Army, Department of Defense, and the NCCUSL (September 27, 2001) (on file with author).

8. Id. at 1.

9. Roster for NCCUSL's Drafting Committee to Uniform Environmental Covenants Act, available at www.environmentalcovenants.org.

10. Id. The National Environmental Justice Advisory Council (NEJAC) is a federal advisory committee that was established by charter on September 30, 1993, to provide independent advice, consuttation, and recommendations to the Administrator of the U.S. Environmental Protection Agency on matters related to environmental justice. For additional information, see www.epa.gov/compliance/environmentaljustice/nejac.

11. Id.

12. UECA, Prefatory Note, at 1-2.

13. Press Release. NCCUSL (March 2003) available at

http://www.environmentalcovenants.org.

14. id.

15. Alex Geisigner, Rethinking Risk-Based Environmental Cleanups, 76 IND. L.J. 367

(2001); Georgette C. Poindexter, Separate and Unequal: A Comment on the Urban

Development Aspects of Brownfield Programs, 24 FORDHAM URB. LJ.. 1 (1996).

16. Kirsten H. Engel, Brownfield Initiatives and Environmental Justice: second-Class

Cleanups or Market-based Equity?, 12 J. NAT. RESOURCES \& ENVTL. L 317, 359

(1998).

17. Memorandum from NCCUSL's Scope and Program Committee to the Joint Editorial

Board on Real Property Acts, regarding "Recommendations of the Study Committee

Concerning a Possible Uniform Environmental Covenants Act ('UECA') and Possible

Amendments to the Uniform Conservation Easement Act" (July 23, 2001) (on file with author).

18. Id

19. UECA $\S 2 \mathrm{cmt} .5$ ("This Act emphasizes that an environmental covenant is a servitude in order to implicate the full body of real property law and sustain the validity and enforceability of the covenant. By first characterizing the environmental covenant as a servitude, the Act expressly avoids the argument that an environmental covenants is simply a personal common law contract between the agency and the owner of the real property at the time the covenant is signed, and thus is not binding on later owners or tenants of that land.").

20. UECA $\S 9(\mathrm{~d})$.

21. UECA §11. Enforcement of Environmental Covenants, provides in pertinent part:

"(a) A civil action of injunctive or other equitable relief for violation of an environmental covenant may be maintained by: (1) a party to the covenant; (2) the [environmental] agency . . ; (3) any person to whom the covenants expressly grants power to enforce; (4\} a person whose interest in the real property or whose collateral or liability may be affected by the alleged violation of the covenants; or (5) a municipality or other unit of local government in which the real property subject to the covenant is located ...." 22. UECA $\$ 6$.

23. UECA $\S \beta$ ont, 
24. UECA, Prefatory Note, at 4 ("This Act does not supplant or impose substantive cleanup standard, either generally or in a particular case. The Act assumes those standards will be developed in a prior regulatory proceeding. Rather, the Act is intended to validate sitespecific, environmental use restrictions resulting from an environmental response project that proposes to leave residual contamination in the ground .... Once the governing regulatory authority and the property owner have determined to use a riskbased approach to cleanup to protect the public from residual contamination, this Act supplies the legal infrastructure for creating and enforcing the environmental covenant under state law ....").

25. UECA $\S \S 9 \& 10$.

26. See Memorandum from Professor William Breetz (Drafting Committee Chair) and Professor Kurt Strasser (Drafting Committee Report) to NCCUSL Uniform

Environmental Covenants Act Drafting Committee, Advisors and Observers 2 (Oct. 22, 2001); See also Edwards, supra note 6, at 8.

27. Engel, supra note 16, at 360 